\title{
Higher Education Economic Impact Studies: Accurate Measures Of Economic Impact?
}

Morgan Bridge, (E-mail: mbridge@mesastate.edu), Mesa State College

\begin{abstract}
Many public institutions of higher education conduct/contract economic impact studies regularly. The accuracy of the economic impact is frequently suspect, since institutions frequently use economic impact as a means to demonstrate their contribution to the local economy in order to justify and increase tax dollars received. Economic impact studies are also used as marketing tools promoting the value of the service being provided to the local community. Hence, the question arises, is it possible for higher education economic impact studies to accurately reflect the dollar value contributed to the economy? Or particularly in the era of tightening budgets due to shrinking state tax revenue, will these types of studies be overstated in order to justify tax dollars received? As Beck and Elliot (1995) have stated, a major criticism of in-house studies is the overstatement of the dollar impact by the institution.
\end{abstract}

Consequently, the strength and credibility of the study may lie in the methodology used to conduct impact studies. With sound methodology, the results may become less suspect. However, there are a variety of differing methodologies used, from the very complicated involving input-output analysis and econometric modeling to the streamlined which involve calculating expenditures and the use of economic multipliers. This paper discusses methodology issues surrounding economic impact studies in higher education. The issues of the long-run versus short-run approach, geographic versus service area, calculation of expenditures, choice of economic multipliers and the labor multiplier, etc., will be discussed.

The impact study conducted by the author will be used as a case study to demonstrate methodology used in a recent economic impact study and to discuss the importance of methodology in the area of college/university impact studies.

\section{INTRODUCTION}

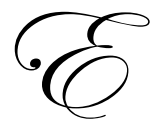

conomic impact studies in higher education are conducted on a regular basis for two primary reasons. The first reason centers around the downturn in state revenues, and the need for publicly funded institutions to use economic impact studies as a means by which to justify tax dollars received and also as a justification to ask for increased tax dollar support. (Potter, 2003) Secondly, institutions also conduct economic impact studies in order to increase the value perceived by their community using the marketing exchange theory. (Stout, 1996) Pride and Ferrell (2003) define the marketing exchange as the transfer of something of value, goods/services, in return for something of value, money or a good/service. Pride and Ferrell state, “....individuals and organizations expect to gain a reward in excess of the costs incurred." Colleges/universities may use economic impact studies to increase their value as perceived by the community as they demonstrate the value added to the community through the college/university economic impact.

Since many state colleges/universities play a major role in the local economy, not only in dollars spent but also in jobs generated, conducting an accurate assessment of the true economic impact of the institution can be useful. However, developing an accurate assessment can be difficult. A plethora of choices must be made that ultimately impact the final number, the economic impact, of the institution on the local economy. The Office of Institutional Research at James Madison University, 1995, states “....an economic impact study is a subjective 
exercise". Beck and Elliott (1995) state, "Economic impact studies of higher education remain an important but controversial public relations tool." This is in large part due to the lack of a common and accepted methodology for conducting such studies. Hence, continued research in this area is imperative. This study contributes in some small part to that body of research as it examines the methodology used, the variety of choices that were made and the impact on the total economic impact through a case study of an economic impact study recently conducted for a small state college.

The focus of this study is the significant economic impact an institution may have on the local economy. Beck and Elliot (1995) define economic impact as, “... the difference between existing economic activity in a region given the presence of the institution and the level that would have been present if the institution did not exist". The primary focus of this study details the economic impact of a state college upon the surrounding area, realizing that institutions of higher education impact the area in which they are located in a variety of ways including increasing the educational level of the workforce or human capital and the cultural impact on the community from an active music/theatre/art department.

When determining the economic impact of an institution of higher education, two approaches may be used. Beck and Elliot cite Kott (1987), Haywood (1993) and Berger and Black (1993) when they distinguish between the long-run approach and the short-run approach to evaluate economic impact. Jafri, Dudley and Buland (2000) and Felsenstein (1996) also address these approaches. The long-run approach looks at the impact on the stock of human capital and the benefits thus received by the community through increased efficiency, enhanced productivity, the development of new technology, the solving of social/health/business problems, lower unemployment rates, the attraction of new businesses due to a skilled labor pool, reduced welfare expenditures, and even areas such as regional economic development, future graduate income and contribution to research and technology produced by the college/university, etc.

Jafri, et al. (2000) continues further and breaks the economic impact into tangible versus intangible benefits. Tangible benefits mirror the long-run approach; however, intangible benefits include such areas as lifetime productivity and inventions/innovations of alumni, and any savings resulting from decreases in social/economic/business/health costs associated with those alumni as well as the "...social benefits (externalities) of education, ...the refinement of the human race, ...quality of life of a community, enjoyment and appreciation of the arts, reading... reduction in crime. " However, attaching accurate numbers to these impact areas is fraught with ambiguity and bias. Thus for the long-run approach/intangible benefits, monetary values are difficult to calculate since externalities have far-reaching implications and monetary costs/benefits.

The short-run approach basically examines the impact on local economic activity induced by the presence of the institution through an analysis of the expenditures incurred by the institution. Consequently, many economic impact studies use the short-run approach to examine the economic activity of the college and the consequent impact on the surrounding community. Forward and backward linkages are estimated in order to determine the economic impact. Items purchased by the college/university such as inputs and supplies are considered backward linkages. Value-added activities such as preparation and processing are considered forward linkages. (Jafri, et al., 2000) Backward linkages will be the focus for this study.

The choice of geographic location is important when conducting an economic impact study. Beck and Elliott, (1995), state that one of the first and most important decisions to be made is choice of geographic area. The greater the geographic area, the more likely the college, employee and student expenditure dollars will remain and comprise a closed economy. Beck and Elliott (1995) also state, "Large residential institutions located in rural areas are likely to have relatively larger direct short-run economic impacts...(and, through expanded access, avoid the departure of local residents and their dollars)".

Mesa State College fits this definition since it is one of the largest of the state colleges on the Western Slope. The college is located in Grand Junction which is the largest retail service hub within a 250 mile radius in all directions and the largest retail hub for the designated counties in this study. For purposes of this study, the surrounding community is determined to be the fourteen county area consisting of Montrose, Delta, Mesa, Eagle, 
Garfield, Grand, Jackson, Moffat, Ouray, Pitkin, Rio Blanco, Routt, San Miguel and Summit Counties. This is also the area for which Mesa State has been designated as the Regional Education Provider, thus its service area. The geographic area chosen was based upon the service area as designated by the state legislature, not necessarily the regional economic area. The leakages out of the area, due to the location, are considered to be small.

Felsenstein (1996) details three approaches used to conduct an economic impact study; the accounting approach which details various expenditures and then uses a multiplier to determine total impact, a regional economic analysis approach which uses input-output and econometric modeling, and a demand-side approach which uses Keynesian income-expenditure multipliers to determine economic impact. The methodology employed for this study will follow the first approach as described by Felsenstein and will rely heavily on the ACE (American Council on Education) methodology developed by Caffrey and Isaacs, (1971), which examines expenditures made by the college, employee expenditures, student expenditures and amounts spent by visitors attending college activities. These numbers are then increased by a multiplier for the total economic impact of the college upon the surrounding community. This study determines the economic impact of Mesa State College for fiscal year 2003-2004 as well as examines the increases in economic activity over the years 1999-2004. The Caffrey and Isaacs (1971) methodology has been heavily employed due primarily to time and monetary constraints. The information needed for this methodology could be obtained, for the most part, from information currently held by the college.

Mesa State College has five areas of expenditures which have an economic impact upon the surrounding community; college expenditures, employee expenditures, capital expenditures, student expenditures and visitor expenditures. College expenditures include those items purchased by Mesa State College from the local community such as printing, janitorial supplies, health care, etc. Employee expenditures include items purchased by the employees of Mesa State such as shelter, clothing, food, etc. Capital expenditures include everything from constructing new buildings to the renovation/refurbishment of existing structures. Student expenditures include those items purchased by students such as food, books and supplies and transportation. Visitor expenditures include such items as food and shelter purchases, stated as a per diem amount, made by visitors as they attend various student/campus activities at Mesa State College. Retiree expenditures, summer school expenditures and noninstitutional income were not included due to time/monetary constraints.

This study breaks down the five categories of expenditures and looks at the direct economic impact of these expenditures on the surrounding community as well as their indirect impact due to the multiplier effect. The multiplier effect takes into consideration that a dollar spent by one individual becomes the income of another person. That initial dollar, since it is being "respent", will have a greater impact on the economy than just the original dollar. Hence, dollars spent "grow" as they are "respent" throughout the economy.

The five sections that follow detail the economic activity for Mesa State College for the five areas over the last five years.

\section{COLLEGE EXPENDITURES}

Mesa State College purchased a variety of items from the surrounding community ranging from printing to janitorial supplies to health care. In order to determine the economic impact of expenditures by Mesa State on the surrounding community, the following methodology was employed. The budgets for all departments and auxiliary accounts were totaled and all items except out-of-state items were included as monies spent by the College.

After reviewing vendor lists supplied by the purchasing department of actual expenditures made, it was determined that approximately $30 \%$ of the dollars spent by the College were spent in the 14 county area surrounding Mesa State. When reviewing the vendor lists, it became apparent that some vendors, for example Wal-Mart, were not considered local vendors since payments were made out of the area. However, realistically, some of those dollars would stay in the area to support jobs at the local stores. Other franchises were similar. Determining the percentage of the dollars that stay in the area could become problematic as the number of franchises in the area increase. 
College expenditures totaled $\$ 47,117,179$ for the years $1999-2004$ and averaged $\$ 9,423,436$ a year. Expenditures increased by approximately 2.4 million over the five-year time frame included in this study. The total dollar amount expended by the College was $\$ 10,965,243$ for $2003-2004$. If $30 \%$ of those dollars were spent in the surrounding community, $\$ 3,289,573$ dollars were added to the local economy by the presence of Mesa State College in 2003-2004.

Mesa State College Expenditures 1999-2004

\begin{tabular}{llcc}
\hline Year & \$Amounts & \%spent locally & Total\$ Added \\
$1999-00$ & $8,534,436$ & $30 \%$ & $2,560,331$ \\
$2000-01$ & $8,900,828$ & $30 \%$ & $2,670,248$ \\
$2001-02$ & $8,953,972$ & $30 \%$ & $2,686,192$ \\
$2002-03$ & $9,762,700$ & $30 \%$ & $2,928,810$ \\
$2003-04$ & $10,965,243$ & $30 \%$ & $3,289,573$ \\
\hline
\end{tabular}

\section{CAPITAL EXPENDITURES}

Capital expenditures were evaluated on a year-to-year basis. During the time frame of this study, several capital projects were completed/continued. The Fine Arts building was constructed during 2000-2002, the technology infrastructure was renovated, and Houston Hall, Walter Walker, Saunders and Tolman underwent major repairs/renovations.

Over the five-years included in the study, $\$ 18,812,587$ was spent on capital projects, with an average spent per year of $\$ 3,762,517$. Of this amount it was estimated that $30 \%$ was spent in the surrounding community, adding $\$ 1,128,755$ to the local economy. Since capital projects vary greatly from year-to-year, a five-year average was used when determining the economic impact for 2003-2004. The 30\% is an estimate and it is highly likely that more dollars were added to the local economy.

Capital Expenditures 1999-2004

\begin{tabular}{llccc}
\hline Year & Projects & \$Amounts & \%Spent Locally & Total\$ Added \\
$1999-00$ & HSSI/WWI & $1,304,972$ & $30 \%$ & 521,989 \\
$2000-01$ & Tech/HHS/WW & $9,004,839$ & $30 \%$ & $3,601,936$ \\
$2001-02$ & HHS/Saun & $6,597,117$ & $30 \%$ & $2,638,847$ \\
$2002-03$ & No new activity & & $30 \%$ & 762,264 \\
$2003-04$ & Tol/WW/HH/Lib & $1,905,659$ & & \\
\hline
\end{tabular}

\section{EMPLOYEE EXPENDITURES}

Employee expenditures include all those items purchased by employees of MSC as they spend their paychecks in the local community. These purchases range from rent/mortgage payments to clothing to entertainment. According to the Bureau of Labor Statistics Consumer Expenditure Survey, housing and transportation are the two largest areas of consumer expenditures. The majority of these dollars spent by MSC employees would stay in the local economy due to the location of Mesa State College as discussed previously. Again retiree and non-institutional expenditures were not included due to time/monetary constraints. 
To determine employee expenditure dollar amounts, all monies budgeted for salaries for all departments and auxiliary accounts were included. Benefits, which included retirement, medical insurance, life insurance, etc. were not included and taxes estimated at $15 \%$ were also subtracted from the salary figures. Consequently, health care dollars were not included in the analysis. Since Grand Junction has excellent health care facilities for a 250 mile radius, again it is likely that many health care dollars actually remain in the local economy. Expenditures were calculated based solely upon the earnings of the Mesa State employee. It is also likely that a second-wage earner in the family would increase expenditures for the Mesa State employee household and consequently, the actual dollars spent would be higher than the employee expenditure numbers stated. (Futhey, 1984)

Mesa State currently employs 1,194 people, according to the Grand Junction Chamber of Commerce. These jobs include full-time faculty and staff, part-time faculty and staff and part-time student employees. MSC is the third largest employer in Mesa County preceded only by School District \#51 and St. Mary's Hospital in number of employees. The College thus has a significant impact on employment levels and consequently economic activity in the surrounding community. The 1,194 which includes full- and part-time jobs equates into 408.4 FTE. FTE are full-time equivalent positions, a number which is comparable to student FTE (full-time students) for reporting purposes.

Due to location, it is assumed there is little dollar leakage out of the area particularly in the major areas of housing, food and transportation. However, vacations and entertainment are examples of dollars that may leave the local economy. Thus, for purposes of this study, it is assumed that $10 \%$ adequately accounts for leakage out of the 14 county area encompassing this study. In order to accurately assess this percentage, a survey of employees would need to be conducted.

Futhey (1984) and Felsenstein (1996) both discussed the importance of the college to the local area and whether or not employees would remain in the area if the institution were to close. It was determined due to location and the isolation of the area, it would be highly likely many faculty, staff and administrators would leave the area if Mesa State were to close. Thus, the following employee expenditure numbers can likely be attributed to the presence of the college. Again, in order to accurately assess this variable, an employee survey would be needed. Consequently, in 2003-2004 employee salaries totaled \$15,425,847 after taxes. Adjusting for leakage, \$13,883,262 was added to the local economy through employee expenditures. This is an increase of approximately $\$ 1.4$ million from fiscal year 1999-2000.

Mesa State College Salary Expenditures 1999-2004

\begin{tabular}{cccc}
\hline Year & Salaries & $\mathbf{- 1 0 \%}$ & Total \$ Added \\
1999 & $13,802,874$ & $1,380,287$ & $12,422,587$ \\
2000 & $14,313,533$ & $1,431,353$ & $12,882,180$ \\
2001 & $15,359,316$ & $1,535,931$ & $13,823,385$ \\
2002 & $15,552,807$ & $1,555,281$ & $13,997,526$ \\
2003 & $15,425,847$ & $1,542,585$ & $13,883,262$ \\
\hline
\end{tabular}

One of the primary target audiences for an economic impact study is area businesses. Local businesses are concerned with the number of dollars spent in their establishments. Thus, using the Bureau of Labor Statistics Consumer Expenditure percentages, the following table demonstrates how those salary dollars were spent in the local economy.

The salary dollars do not include benefits, are adjusted for after-tax dollars and are adjusted for leakage out of the area. The table assumes an average income of $\$ 40,000-\$ 49,999$ for the Midwest Region, using the BLS percentages for the years 2001-2002, the most recent values available. 
MSC Employee Expenditures by Category 2003-2004

\begin{tabular}{|c|c|c|}
\hline \multicolumn{3}{|l|}{ Food } \\
\hline Food at home & $7.44 \%$ & $1,032,915$ \\
\hline Food away from home & $5.40 \%$ & 749,696 \\
\hline Total Food & $12.84 \%$ & $1,782,611$ \\
\hline Alcoholic Beverages & $1.25 \%$ & 173,541 \\
\hline \multicolumn{3}{|l|}{ Housing } \\
\hline Shelter & $16.65 \%$ & $2,311,563$ \\
\hline Utilities, fuels, and public services & $6.75 \%$ & 937,120 \\
\hline Household operations & $1.22 \%$ & 169,376 \\
\hline Housekeeping supplies & $1.33 \%$ & 184,647 \\
\hline Household furnishings and equipment & $3.79 \%$ & 526,176 \\
\hline Total Housing & $29.74 \%$ & $4,128,882$ \\
\hline \multicolumn{3}{|l|}{ Apparel and services } \\
\hline Men and boys & $1.01 \%$ & 140,221 \\
\hline Women and girls & $1.57 \%$ & 217,967 \\
\hline Children under 2 & $0.24 \%$ & 33,320 \\
\hline Footwear & $0.66 \%$ & 91,630 \\
\hline Other apparel products and services & $0.53 \%$ & 73,581 \\
\hline Total Apparel and services & $4.01 \%$ & 556,719 \\
\hline Transportation & $20.97 \%$ & $2,911,320$ \\
\hline Health Care & $6.16 \%$ & 855,209 \\
\hline Entertainment & $4.70 \%$ & 652,513 \\
\hline Personal care products and services & $1.21 \%$ & 167,987 \\
\hline Reading and education & $1.96 \%$ & 272,112 \\
\hline Tobacco products and smoking supplies & $1.31 \%$ & 181,871 \\
\hline Miscellaneous & $1.89 \%$ & 262,394 \\
\hline Cash contributions & $3.19 \%$ & 442,876 \\
\hline Personal insurance and pensions & $9.99 \%$ & $1,386,938$ \\
\hline Total Differences are due to rounding errors. & $99.22 \%$ & $13,774,973$ \\
\hline
\end{tabular}

\section{STUDENT EXPENDITURES}

As students attend Mesa State College, many dollars are spent in the local economy, again, in large part due to the location of MSC. Student expenditures by local residents who choose to attend MSC are included in the total dollars spent, due to the fact they remain in the area due to the presence of MSC instead of relocating to a new area in order to obtain their college education. Duhart (2002) made the same assumption in her study of the Georgia University System and discussed the importance of evaluating this assumption. Again, a survey would need to be conducted in order to determine if Mesa State students would leave the area to attend college or simply no longer attend college but remain in the local area if not for the presence of Mesa State College.

The expenditure amounts were determined by the formula used by the Financial Aid Office at Mesa State College. Non-tuition student expenditures were broken into five groups; books and supplies, board, personal expenses, room and transportation. Tuition/fee dollars were not included to avoid double-counting since tuition/fee dollars in part finance college expenditures. The same expenditure amounts were used for both on- and off-campus students. It is assumed that $90 \%$ of these dollars remained in the local economy. Again, in order to more accurately assess dollars spent, a student survey would need to be conducted. 
The increase in dollars spent is indicative of the increase in student population. The student headcount fall 1999 was 4,893 students attending Mesa State College. The student headcount fall 2003 was 5,725. Thus with an increase of 832 students, dollars spent in the surrounding economy have also increased. Over the last five years, there has been an increase of $\$ 14.7$ million dollars added to the economy by a growing Mesa State College student body. On average, 5,725 students spent \$1,186 a month while attending Mesa State College during the 2003-2004 school year alone.

\section{MSC Student Expenditures 1999-2004}

\begin{tabular}{llll}
\hline Year & Student\$ Spent & $\mathbf{- 1 0 \%}$ & Total\$ Added \\
$1999-00$ & $46,336,710$ & $4,633,671$ & $41,703,039$ \\
$2000-01$ & $49,291,359$ & $4,929,135$ & $44,362,224$ \\
$2001-02$ & $55,714,406$ & $5,571,440$ & $50,142,966$ \\
$2002-03$ & $59,147,280$ & $5,914,728$ & $53,232,552$ \\
$2003-04$ & $61,120,100$ & $6,112,010$ & $55,008,090$ \\
\hline
\end{tabular}

\section{VISITOR EXPENDITURES}

Visitor expenditures include all those items purchased by visitors as they attend Mesa State College activities/events. As visitors attend MSC events, they purchase lodging, food, entertainment and fuel. Also, since these dollars are out of area dollars, they are "new" dollars to the community. The per diem amount of $\$ 98$ was obtained from the Department of Defense for the MSA of Grand Junction, Colorado.

In order to determine the number of visitors to Mesa State College, the various areas listed below were asked to provide their visitor numbers for the year 2003. The following table contains the information provided by the various areas. It was assumed these visitors spent only one day in the area while attending MSC events.

Of these 131,324 visitors, it is estimated that $30 \%$ were from out of the area and spent dollars in Mesa County due to the presence of Mesa State College. Thus, 39,397 people visited the area in 2003 attending Mesa State College activities. Using $\$ 98$ as the per diem amount, $\$ 3,860,906$ was spent by visitors attending events at Mesa State College in 2003. Again, a student/visitor survey would need to be conducted in order to obtain a more accurate number of visitors. The various areas within the college would also need to keep more accurate numbers in order to more accurately assess this expenditure category. Also length of stay would be an important variable to track.

\section{Number Of Mesa State Visitors By Area}

\begin{tabular}{lr}
\hline Area & \#of visitors \\
& \\
Tomilson Library & 5,250 \\
Performing Arts & 8,000 \\
College Center & 66,805 \\
Athletics & 46,269 \\
Graduation (estimate) & $\underline{5,000}$ \\
Total & 131,324 \\
\hline
\end{tabular}




\section{MULTIPLIER EFFECT}

The multiplier effect is important to consider when determining the total economic impact of Mesa State College on the surrounding community. Due to the multiplier effect, any time dollars are spent, that dollar spent increases as it travels through the economy as it becomes another person's income. Thus the economic impact is not just the original dollar but the dollar multiplied by an additional increase, the multiplier. Thus, since the dollars spent by Mesa State College grow into the income of others as they are spent in the surrounding community, the total economic impact of Mesa State is determined by multiplying the total original dollars spent by the multiplier.

When reviewing similar studies, a variety of multipliers have been used to calculate the multiplier or indirect effect of dollars spent in the surrounding community. The following table lists differing studies and the multipliers used for those studies.

\section{Economic Multipliers Used In Selected Economic Impact Studies}

\begin{tabular}{lc}
\hline James Madison University (The Economic Impact, 1995) & $1.18-1.43$ \\
Tarelton University (Jafri, Dudley and Buland, 2000) & $1.17-1.91$ \\
Northern Arizona (A Sound Investment, 2000) & 3.49 \\
University System of Georgia Institutions (Duhart, 2002) & 1.56 \\
University of Wisconsin-Madison (A Sound Investment, 2000) & 2.24 \\
University of Colorado (A Sound Investment, 2000) & $1.93-2.06$ \\
University of Colorado Health Sciences (A Sound Investment, 2000) & $2.06-2.5$ \\
CSU (Economic Impact, 2000) & 4 \\
National Association of State Universities and Land-Grant Colleges (1997) & $3.8-4.6$ \\
Mesa State (1992) RIMS and WICHE (Halsey, 1992) & $1.4-2.7$ \\
Mesa State (1999) RIMS Multipliers (Economic Strategy Center, Inc., 1999) & $1.595-1.87$ \\
VCB Grand Valley RIMS Multipliers (Adams) & $1.477-2.649$
\end{tabular}

The listed studies used a variety of approaches when determining the choice of an economic multiplier. IMPLAN was widely used to calculate the multipliers for specific areas. The RIMS multipliers were used as well as many studies that "guessed" or "averaged" the multiplier for that study. For this study a multiplier of 1.8 was chosen, which is conservative when examining the above numbers. The "guess approach" was the methodology chosen. However, when examining the previous MSC impact studies which used the RIMS multipliers, the 1.8 chosen for this study was very conservative. In order to make comparisons from previous studies, using the same multiplier would be beneficial. In order to accurately determine a multiplier, appropriate input-output analysis would need to be conducted.

The total economic impact of Mesa State College may be greater than the number generated by this study due to the conservative multiplier used. When calculating expenditures of $\$ 77,170,586$ and using a multiplier of 1.8, the total economic impact of Mesa State College for 2003-2004 was \$138,907,055.

Economic Impact Of Mesa State College 2003-2004

\begin{tabular}{llccc}
\hline & Direct Impact & Indirect Impact & Total Impact & \% of total \\
College Ex. & $3,289,573$ & 1.8 & $5,921,231$ & $4.3 \%$ \\
Capital Ex. & $1,128,755$ & 1.8 & $2,031,759$ & $1.5 \%$ \\
Employee Ex & $13,883,262$ & 1.8 & $24,989,872$ & $17.9 \%$ \\
Student Ex. & $55,008,090$ & 1.8 & $99,014,562$ & $71.3 \%$ \\
Visitor Ex. & $3,860,906$ & 1.8 & $6,949,631$ & $5.0 \%$ \\
Total & $77,170,586$ & & $138,907,055$ & $100 \%$
\end{tabular}

*Note: In order to avoid distorted numbers caused by differing multipliers and inflation over time, the total impact was calculated for the year 2003-2004 only. 


\section{Labor Multiplier}

\section{Total Economic Impact of Mesa State College 2003-2004 By} Expenditure Category

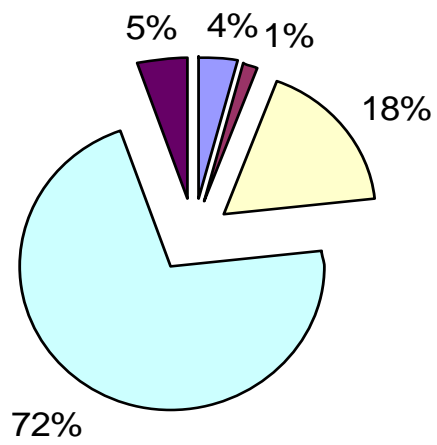

$\square$ College Exp $\square$ Capital Exp $\square$ Employ Exp $\square$ Student Exp - Visitor Exp

A labor multiplier can then be used to calculate the number of jobs created by the influx of the $\$ 77,170,586$ into the surrounding community. These are jobs created in order to service original jobs. Again as selected studies were reviewed, differing labor multipliers were used. The following table looks at a variety of studies and the labor multipliers used in those studies.

\section{Labor Multipliers Used In Selected Economic Impact Studies}

Springfield Community College (O’Brien, 2003)

Again, the methodology used in order to determine the labor multiplier was varied. Many studies used total dollars spent and then calculated the labor multiplier based upon this number for their specific geographic location. Again in order to obtain a more accurate number, appropriate analysis must occur. For this study, a labor multiplier of 1.4 was used to estimate the additional number of jobs created in order to service expenditures made by Mesa State College employees. Using the current 1,194 employees at MSC, and the labor multiplier of 1.4, an additional 477 jobs have been created due to the presence of MSC. These 477 jobs include not only full-time faculty and staff positions but also part-time faculty and staff positions and part-time student positions. 
Instead of using jobs, FTE can be used to calculate the number of jobs created. Taking the 408.4 FTE currently at Mesa State and using the multiplier of 1.4, FTE of 571.76 were created. FTE are full-time equivalent positions, a number which is comparable to student FTE (full-time students) for reporting purposes.

Calculating jobs created in yet another way, the $\$ 138,000,000$ in total impact would be spent in the community. Of that $\$ 138,000,000$, wages and salaries would account for $5.3 \%$ according to the industry survey from BizStats.com. The $\$ 138,000,000$ multiplied by $5.3 \%$ would create $\$ 7,314,000$ in salaries/wages paid. Using retail, and a 2000 hour job at $\$ 7.00$ an hour, 522 jobs would be created from the original $\$ 138,000,000$. Again, the methodology used will provide differing results, although, the above numbers are comparable giving credence to the 1.4 labor multiplier chosen for this particular study.

As can be seen throughout this report, Mesa State College has a significant impact on the 14 counties contained in the study. The economic impact is significant as the direct impact of the $\$ 77$ million dollars spent turned into $\$ 138$ million as the dollars multiplied throughout the area.

Due to the scope of this study, some areas of expenditures were not included; retiree expenditures, summer classes and non-institutional income such as consulting, thus in effect lessening the total economic impact of Mesa State. One of the major criticisms of economic impact studies that are created in-house is the temptation to increase the numbers, use larger multipliers and thus overstate the economic impact of the college on the surrounding community. (Beck and Elliot, 1995) This study has used a very conservative approach in totaling dollars spent in only five differing areas, multipliers used and the total economic impact of Mesa State College. Consequently, it is likely that the economic impact of Mesa State College is actually larger than stated in this study.

A major concern whenever conducting research is the cost/benefit analysis. In order to accurately assess many of the areas discussed in this study, additional research would have had to occur. The increase in research would also increase the cost of the study. The question then arises, is the additional information gained worth the cost of obtaining the information? Does the addition or deletion of several million dollars actually make a difference? Returning to the original question posited at the beginning of the paper, for what purpose is the economic impact study conducted? From a marketing perspective, few people would argue that a college/university does not add value to the community in which it resides. Arguing the justification of tax dollars, few people would disagree with the fact colleges/universities impact the local communities. The question then addressed by the economic impact study only details by what amount does the college/university impact the local/state economy.

Until a more uniform methodology which is cost effective is agreed upon, economic impact studies will continue to be conducted using a variety of approaches. The short-run or expenditure approach is the least-costly approach since it is based upon dollars actually spent and already recorded. However, even using this methodology many differing values for economic impact can be obtained. Research must continue using the long-run (externality) approach. This may actually be the approach where the true benefits of a college/university are supported. However, externalities remain a difficult area to evaluate in all arenas, not just education. Until these issues are resolved, economic impact studies will remain suspect but as a public relations tool and a tax dollar justification tool, they will continue to be conducted.

\section{REFERENCES}

1. Adams, Tucker Hart, "The Impact of Tourism on the Grand Valley Economy: A Sound Investment in Colorado", University of Colorado, Economic Impact, 2000.

2. Beck, Roger and Donald Elliott, "Economic Impact Studies of Regional Public Colleges and Universities", Growth and Change, Vol. 26(2), spring 95.

3. Duhart, Sharon, R., "The Economic Impact of University System of Georgia Institutions on Their Regional Economies. A Needs Assessment Study Commissioned by Georgia's Intellectual Capital Partnership Program", ERIC ED469340, 2002.

4. "Economic Impact in Colorado", Colorado State University, 2000. 
5. "The Economic Impact of James Madison University on the Harrisonburg/Rockingham County Area and the Commonwealth of Virginia", James Madison University Office of Institutional Research, 1995.

6. "Economic Impact of Mesa State College on the Local Economy", Economic Strategy Center, Inc., 1999.

7. Felsenstein, Daniel, "The University in the Metropolitan Area: Impacts and Public Policy Implications", Urban Studies, Vol. 33(9), 1996.

8. Futhey, Carol, "Northern Kentucky University: Contributions to the Region's Education, Quality of Life and Economy", Northern Kentucky University, 1984.

9. Grand Junction Economic Partnership, 2004, www.gjep.org.

10. Halsey, Christopher, J., "Economic Impact of Mesa State College on Mesa County", Western Colorado Bureau of Economic Research, 1992.

11. Jafri, Hussain, Dudley, Jay and David Buland, "Economic Impact of Tarleton State University", Tarleton State University, 2000.

12. O'Brien, George, "Fueling the Region's Economy”, www.BusinessWest.com, April 2003.

13. Pride, William and O.C. Ferrell, Marketing, Houghton Mifflan, 2003.

14. Potter, Will, "Public Colleges Try to Show Their Value to States, Not Everyone is Convinced", Chronicle of Higher Education, Vol. 49(35), 2003.

15. Stout, Robert, J. "Community Attitudes about Economic Impacts of Colleges: A Case Study", ERIC ED397737, 1996.

16. "Value Added: The Economic Impact of Public Universities", National Association of State Universities and Land-Grant Colleges, ERIC ED416778, 1997. 


\section{NOTES}

